\title{
STRATEGI PENGELOLAAN SUMBERDAYA PESISIR DI DESA PEMUTERAN, KECAMATAN GEROKGAK KABUPATEN BULELENG
}

\section{Ni Luh Putu Trisna Ika Putri ${ }^{1}$, I Putu Ananda Citra ${ }^{2 *}$}

Pendidikan Geografi, Universitas Pendidikan Ganesha, Indonesia

\author{
A R T I C L EIN F O \\ Article history: \\ Received 19 Desember \\ 2017 \\ Received in revised form \\ 6 Februari 2018 \\ Accepted 12 Maret 2018 \\ Available online 31 Maret \\ 2018 \\ Kata Kunci: \\ Potensi \\ Sumberdaya \\ Pesisir \\ Pengelolaan \\ Keywords: \\ Potential \\ Coastal \\ Resources \\ Management
}

\begin{abstract}
A B S T R A K
Penelitian dilaksanakan di Desa Pemuteran dengan tujuan: (1) Memetakan sebaran potensi sumberdaya pesisir, (2) Mendeskripsikan kendala dalam pengembangan sumber daya pesisir, (3) Menganalisis strategi dalam pengembangan sumber daya pesisir. Penentuan sampel menggunakan teknik purposive sampling. Data dikumpulkan dengan teknik observasi, wawancara, dokumentasi, dan pencatatan dokumen. Metode analisis yang digunakan yaitu analisis kualitatif dan analisis SWOT.Hasil penelitian menunjukkan: (1) Pesisir Desa Pemuteran memiliki potensi sumberdaya pesisir yang sudah dikembangkan yaitu sumberdaya hayati, sumberdaya non-hayati, sumberdaya buatan dan jasa-jasa lingkungan, (2) Kendala dalam pengelolaan potensi sumberdaya pesisir diantaranya keterbatasan sarana pemasaran ikan dan pengolahan ikan, rendahnya kualitas sumber daya manusia, (3) Strategi pengelolaan sumberdaya pesisir di Desa Pemuteran diantaranya: a) sumberdaya ikan; b) pelestarian terumbu karang,; c) pariwisata dalam hal pelatihan pelayanan wisata; d) kerajinan.
\end{abstract}

\section{A B S T R A C T}

The research was conducted in Pemuteran Village with the aim of: (1) To map the potential distribution of coastal resources, (2) Describe in the development of coastal resources, (3) Analyze Strategy in developing coastal resources. The research design is descriptive. Determination of sample using purposive sampling technique. Data with observation techniques, interviews, and document recording. Analytical methods used are qualitative analysis and SWOT analysis. The results showed: (1) Coastal Pemuteran Village has the potential of coastal resources that have been developed that are biological resources, non-biological resources, artificial resources and environmental services, (2) Obstacles in the management of coastal resources potency in Pemuteran village excess fish marketing and fish processing facilities, low quality of human resources in maintaining coral reef ecosystem, (3) Strategy of coastal resources management in Pemuteran Village: a) source of marine fish cultivation fish, providing fish market; b) coral reef conservation; c) tourism in the case of tourism service training; d) crafts provide capital to the community in the field of business which is occupied in the Village Pemuteran.

\footnotetext{
* Corresponding author.

E-mail addresses:ikakputrik@yahoo.com (Penulis Pertama), ananda.citra@undiksha.ac.id (Penulis Kedua)
} 


\section{Pendahuluan}

Indonesia merupakan negara kepulauan yang terletak di antara benua Asia dan Australia serta di antara Samudera Hindia dan Pasifik (Sadono, 2017). Sebagai negara kepulauan, laut merupakan wilayah terluas dibandingkan daratan di Indonesia sehingga sebagian besar masyarakat Indonesia tinggal di sepanjang garis pantai yang menyebabkan masyarakat di daerah pesisir bekerja dan menggantungkan hidupnya pada potensi laut sebagai nelayan (Sudiartawan, Treman, \& Budiarta, 2017). Wilayah pesisir merupakan pertemuan antara darat dan laut. Ke arah darat wilayah pesisir meliputi meliputi bagian daratan, baik kering maupun terendam air, yang masih dipengaruhi sifat-sifat laut seperti pasang surut, angin laut, dan perembesan air asin. Sedangkan ke arah laut wilayah pesisir mencakup bagian laut yang masih dipengaruhi proses-proses alami yang terjadi di darat seperti sedimentasi dan aliran air tawar, maupun yang disebabkan oleh kegiatan manusia di darat seperti penggundulan hutan dan pencemaran (Soegiarto dalam Dahuri, 1999). Wilayah pesisir merupakan pertemuan antara darat dan lautan yang masih bersifat darat atau masih terdapat adanya aktivitas ekonomi dari masyarakat, maka dari itu dapat disebutkan bahwa wilayah pesisir masih dapat dijangkau oleh penduduk dan masih ada campur tangan manusia. Wilayah pesisir memiliki arti strategis karena merupakan wilayah peralihan (interface) antara ekosistem darat dan laut, serta mempunyai potensi sumber daya alam dan jasa-jasa lingkungan yang sangat kaya (Sutrisno, 2014).

Indonesia negara kepulauan terbesar di Asia. Sebanyak 2/3 wilayahnya merupakan lautan dan $1 / 3$ wilayahnya merupakan daratan, yang memiliki berbagai macam budaya, dan dianugrahi alam yang kaya dan subur. Potensi kelautan Indonesia sangat besar dan beragam yakni memiliki 17.508 pulau dengan garis pantai sepanjang $81.000 \mathrm{~km}$ dan 5,8 juta $\mathrm{km}^{2}$ laut atau sebesar 70\% dari luas total Indonesia. Potensi tersebut tercermin dengan besarnya keanekaragaman hayati, potensi budidaya perikanan pantai ,laut dan pariwisata bahari(Budiharsono, 2001).

Sumber daya pesisir menjadi modal dasar dalam pembangunan yang penting bagi pembangunan ekonomi Indonesia pada masa yang akan datang (Waluyo, 2014). Pulau Bali merupakan salah satu pulau yang memiliki keberagaman wilayah pesisir yang indah dan berpotensi dalam pengembangannya. Pengembangan wilayah pesisir harus mengikuti pola keberlanjutan dan keterpaduan agar pemanfaatan wilayah pesisir tidak merugikan satu sama lain (Khakhim, Soedharma, Mardiastuti, Siregar, \& Boer, 2008). Pulau Bali memiliki 9 kabupaten, namun Pengelolaan yang kurang menimbulkan kesinambungan dan kesenjangan pembangunan wilayah pesisir di Pulau Bali bagian utara. Kabupaten yang terdapat di Bali utara dengan kategori kabupaten terluas dengan pantai yang terpanjang di Bali adalah Kabupaten Buleleng.

Kabupaten Buleleng merupakan salah satu Kabupaten yang memiliki wilayah pesisir paling luasterletak di Utara Pulau Bali dengan pengelolaan pesisir yang kurang optimal, hal ini dapat ditunjukkan dari data kunjungan wisatawan yang masih rendah.Kabupaten Buleleng yang memiliki wilayah hampir sepertiga dari pulau Bali menyimpan potensi daya tarik wisata alam. Didukung dengan letak Kabupaten Buleleng yang Nyegare-Gunung yakni terletak di antara perbukitan dan wilayah pesisir pantai. 
Potensi Sumberdaya Pesisir seperti terumbu karang yang sedang dikembangkanoleh salah satu desa di Kecamatan Gerokgak yaitu Desa Pemuteran.

Terumbu karang merupakan ekosistem yang bersifat dinamis dan terintegrasi dengan bahan penyusun mineral yang disumbangkan oleh hewan dan tanaman(AsSyakur \& Wiyanto, 2016). Terumbu karang sebagai salah satu sumber daya alam di kawasan pesisir Buleleng memiliki gugusan karang yang sangat khas (Yudasmara, 2016). Terumbu karang memiliki berbagai peranan penting dalam tatanan lingkungan kawasan pesisir dan lautan baik ditinjau dari segi biologi dan ekologi maupun biotanya (Uar, Murti, \& Hadisusanto, 2016). Kesadaran akan pentingnya terumbu karang, masyarakat mulai ikut melestarikan terumbu karang dan menjaga kebersihan lingkungan di bawah laut. Pengelolaan pesisir di Desa Pemuteran masih di bawah naungan Desa Adat, sehingga segala aktifitas yang menyangkut upaya pelestarian sumberdaya pesisir masih dalampengawasan desa adat yang diberi nama (IP3) Ikatan Pelaku Pariwisata Desa Pemuteran.

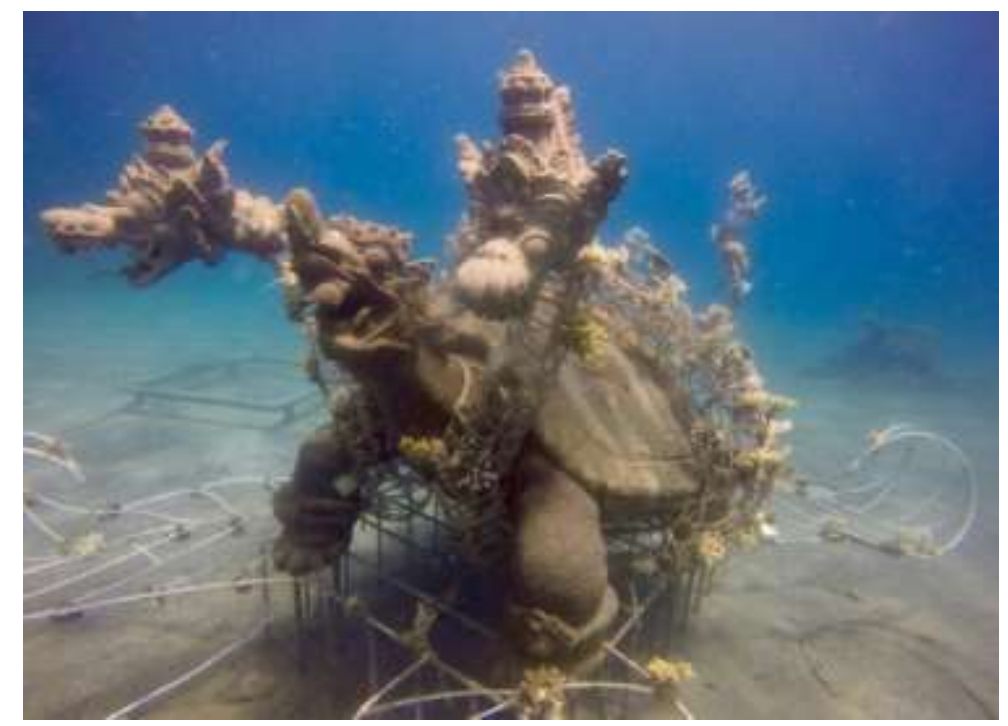

Gambar 1.Terumbu Karang di Desa Pemuteran

Terumbu karang yang sehat akan memberikan berbagai manfaat. Seperti terjaminnya keberlangsungan biota laut lain yang menunjang masyarakat setempat. Nelayan merupakan mata pencaharian utama masyarakat masyarakat Desa Pemuteran,sehingga diupayakan strategi dalam pengelolaan Sumberdaya Pesisir yang membuka peluang usaha untuk masyarakat yang lebih luas Berdasarkan uraian tersebut menarik untuk dilakukan penelitian tentang Strategi Pengelolaan Sumberdaya pesisir di Desa Pemuteran.

\section{Metode}

Penelitian berlokasi di Desa Pemuteran, Kecamatan Gerokgak, Kabupaten Buleleng.Objek dalam penelitan ini adalah potensi dan pengelolaan sumberdaya pesisir di Desa Pemuteran. Berdasarkan objek penelitian, yang menjadi subjek penelitian 
adalah wilayah masyarakat yang terkait dengan pemanfataan dan pengelolaan sumberdaya pesisir di Desa Pemuteran. Penelitian ini menggunakan racangan penelitian deskriptif.Data yang digunakan adalah data primer dan sekunder. Data sekunder bersumber dariKantor Desa Pemuteran, BPS Kabupaten Buleleng, dan instansi pemerintah yang terkait. Data primer diperoleh langsung dari subjek penelitian (informan kunci). selanjutnya akan dianalisis menggunakan analisis deskriptif kualitatif dengan menggunakan pendekatan keruangan.Strategipengelolaan potensi sumberdaya pesisir Desa Pemuteran akan dianalisis menggunakan metode deskriptif dengan analisis SWOT.

\section{Hasil dan Pembahasan}

\subsection{Potensi Sumberdaya Pesisir di Desa Pemuteran Kecamatan Gerokgak}

a. Sumberdaya Hayati

Terumbu karang di Desa Pemuteran memiliki peranan sangat penting bagi kehidupan masyarakat pesisir di Desa Pemuteran. Secara ekologi terumbu karang memiliki manfaat yaitu (1) secara langsung terumbu karang menjadi penunjang kehidupan berbagai jenis makhluk hidup yang ada di sekitarnya sebagai tempat tinggal, mencari makan dan berkembang biak bagi biota laut, (2) terumbu karang mampu memperkecil energi ombak yang menuju ke daratan, sehingga mencegah terjadinya abrasi pantai. Terumbu karang secara langsung maupun tidak langsung menjadi sumber ekonomi bagi masyarakat. Keberadaanterumbu karang menunjang perekonomian masyarakat pesisir di Desa Pemuteran.

Pengembangan terumbu karang menjadi objek wisata mampu menciptakan berbagai lapangan pekerjaan bagi masyarakat di Desa Pemuteran.

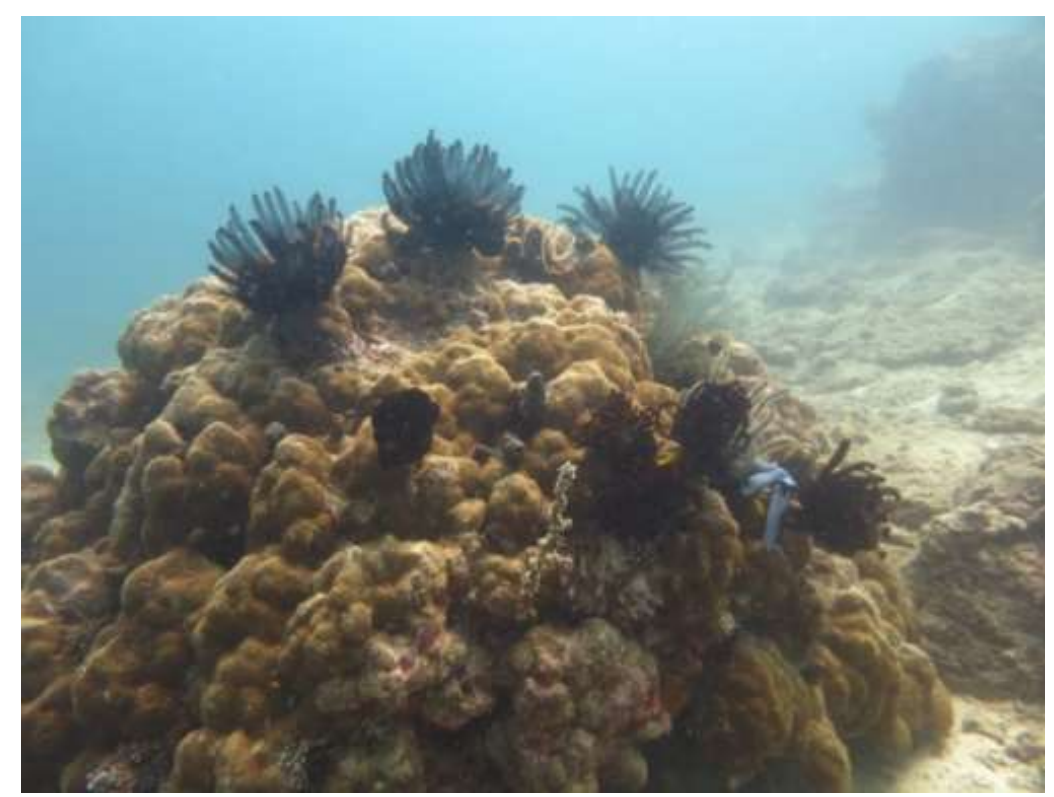

Gambar 2 Terumbu Karang

(Sumber: Ika Putri, 2017) 
Desa Pemuteran kini memiliki taman koral seluas 2,5 hektar yang dibangun dengan teknik biorock atau teknologi percepatan pertumbuhan terumbu karang dengan aliran listrik untuk menstimulus pertumbuhan karang Arus listrik tersebut dialirkan ke struktur-struktur yang menjadi media tanam terumbu karang Dengan adanya bantuan arus listrik pertumbuhan terumbu karang bisa dipercepat 6-8 kali lebih cepat.Kinimenjadi kebanggaan masyarakat Desa Pemuteran Buleleng Bali. Keindahan taman karang menjadi daya tarik tersendiri, sehingga kini ramai di kunjungi wisatawan.

Perikanan di Desa Pemuteran pada saat ini memiliki hasil tangkapan yang cukup banyak, melihat dari pelestarian biota laut yang kini dijalankan. Banyak ikan yang di hasilkan, mulai dari ikan snapper, ikan terbang, ikan teri, ikan awan, ikan cakalang, ikan kerapu. Jenis-jenis ikan tersebut memang banyak ditemukan di laut bali bagian utara. Ikan merupakan potensi sumberdaya pesisir utama bagi masyarakat pesisir. Ketika nelayan melaut hasil tangkapan rata-rata 20 kilogram.

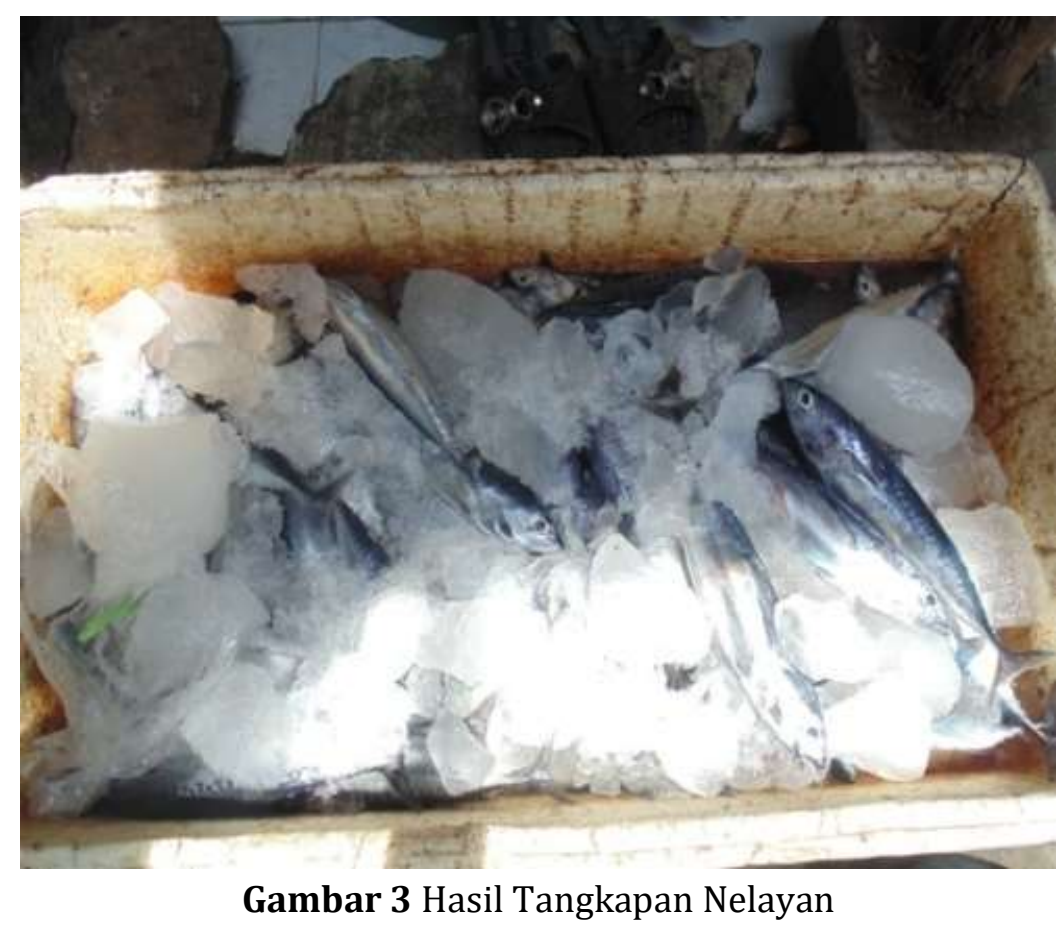

(Sumber: Ika Putri, 2017)

Akomodasi penangkapan ikan yang digunakan nelayan di Desa Pemuteran adalah jukung dan boat. Penangkapan ikan oleh nelayan menggunakan jukung sangat banyak digunakan, hal ini dikarenakan jukung sangat efektif digunakan di perairan manapun. Selain itu alat penangkapan ikan yang digunakan oleh nelayan di Desa Pemuteran masih tergolong tradisional atau sederhana yaitu pancing dan jaring.Pancing dan jaring merupakan alat ramah lingkungan karena sebelumnya pernah menggunakan bom dan potassium, selain itu pancing dan jaring lebih efektif dan dapat menangkap ikan dalam jumlah banyak. Hasil tangkapan ikan para nelayan di Desa Pemuteran biasanya langsung dijual ke konsumen atau untuk konsumsi sendiri. 


\section{b. Sumberdaya Non-Hayati}

Desa Pemuteran terletak di bawah perbukitan dengan hutan yang menghijau dan diutara berupa hamparan laut yang sangat luas dengan pantai pasir putih dan hitam. Pantainya memiliki garis pantai sepanjang $6 \mathrm{~km}$, di sebuah teluk yang sangat indah. Kehidupan disini sangat tenang karena sebagaian besar penduduk sebagai petani dan nelayan, rutinitas yang sudah berlansung sejak lama dan memang dilestarikan.

Desa pemuteran merupakan desa yang memiliki pesisir yang indah, selain pasir yang berwarna hitam pasir yang berwarna putih merupakan tujuan utama wisatawan untuk menikmati suasana pantai. Hal inilah yang dimiliki desa pemuteran yang menjadi salah satu desa tujuan wisatawan mancanegara. Pasir yang berada dipesisir pantai pemuteran, tidak dikelola oleh masyarakat setempat. Namun hanya dijadikan objek untuk para pengunjung yang ingin berlibur atau menikmati suasana.

Garam merupakan salah satu kebutuhan yang di perlukan oleh masyarakat pada umumnya, garam yang diproduksi oleh salah satu masyarakat desa pemuteran memiliki keunikan tersendiri. Dapat dilihat dari bentuk bentuk yang dihasilkan, garam yang dihasilkan memilki keunikan tersendiri yaitu berbentuk piramid.

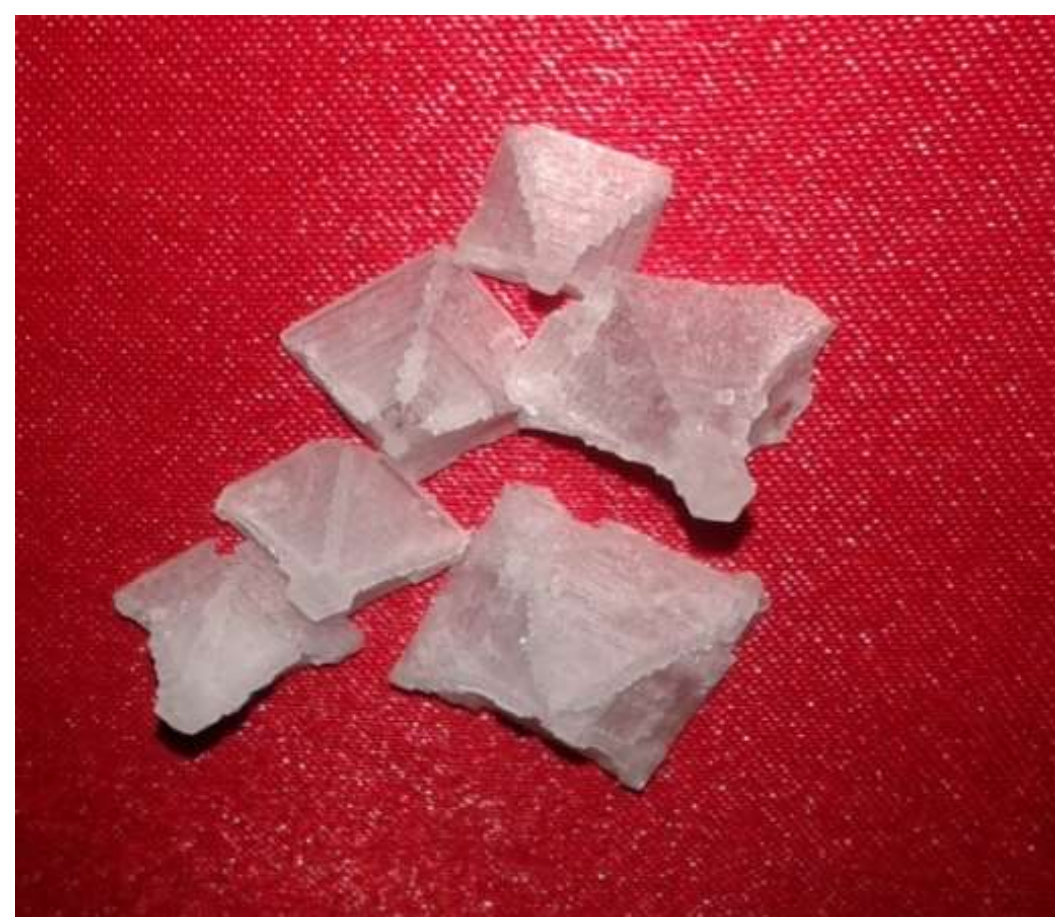

Gambar 4 Garam Piramid

(Sumber: Ika Putri, 2017)

Garam yang telah di produksi di Desa Pemuteran memiliki kualitas yang baik begitu pula dengan harganya berada pada kisaran Rp. 70.000 hingga Rp. 200.000. Produksi sekali panen garam ini mencapai 1 hingga 2 ton perbulan, itupun melihat dari kondisi cuaca yang baik atau sedang panas, jika sedang musim hujan, produksi bisa 
mencapai 2 bulan. Pemasaran hasil produksi garam Bali Artisant Salt ini langsung di ekspor sendiri ke Luar Negeri yaitu Eropa. Ruangan yang digunakan dalam pengelolaan garam ini berupa rumah kaca.

\section{c. Sumberdaya Buatan}

Sumberdaya buatan yaitu potensi yang dapat mendukung kegiatan di wilayah pesisir Buleleng yang dibuat oleh manuasia atau masyarakat sekitar. Adapun sumber daya buatan yag terdapat di wilayah pesisir yaitu salah satunya dermaga. Namun dermaga di desa pemuteran pada saat ini sedang mengalami kerusakan, hal ini dikarenakan kurangnya perhatian dari masyarakat maupun desa adat itu sendiri, terbengkalainya dermaga sehingga dikelola oleh orang luar yang sering berlabuh yaitu kapal dari jepang yang mengambil ikan di Desa Pemuteran.

Biorock adalah suatu proses teknologi deposit elektro mineral yang berlangsung di dalam laut, biasanya disebut juga dengan teknologi akresi mineral.Biorock bekerja menggunakan proses elektrolisis air laut, yaitu dengan meletakkan dua elektroda di dasar laut dan dialiri dengan listrik tegangan rendah yang aman sehingga memungkinkan mineral pada air laut mengkristal di atas elektroda. Biorock dibentuk dengan menggunakan struktur ram besi non-galvanisasi sebagai katoda dan karbon, timah atau titanium sebagai anoda. Saat dialiri listrik, struktur biorock ini menimbulkan reaksi elektrolitik yang mendorong pembentukan mineral di struktur katoda. Mineral yang mengendap adalah kalsium karbonat dan magnesium hidroksida. Kedua mineral ini penting karena merupakan struktur dasar dari terumbu karang. Karena pengakresian mineral yang terjadi secara cepat, bibit terumbu karang yang ditanamkan ke struktur biorock dapat tumbuh secara cepat. Endapan mineral ini juga melekatkan struktur dengan dasar laut dan memperkuat struktur.

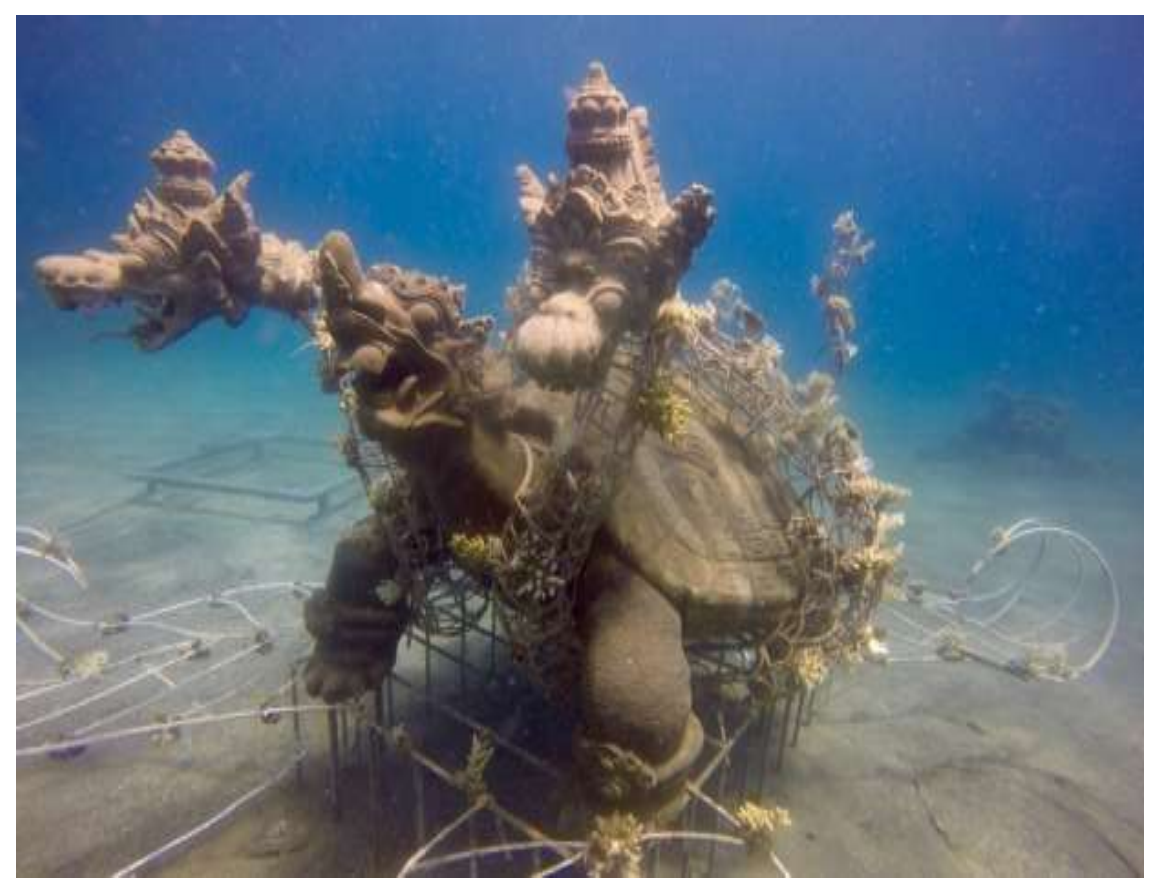


Gambar 5 terumbu karang Biorock Pemuteran

(Sumber: Pengelola Biorock, 2017)

\section{d. Jasa-jasa lingkungan}

Jenis layanan wisata bahari yang terdapat di Desa Pemuteran adalah diving. kegiatan menyelam dengan menggunakan alat bantu pernafasan dengan menggunakan udara dari tabung udara. Udara yang digunakan di dalam tangki adalah oksigen murni. untuk melakukan Diving, penyelam tidak bisa sembarangan. Ada sertifikasi yang harus dilakukan sebelum penyelam bisa (diizinkan) oleh instruktur. Untuk biaya diving di Pemuteran dapat menikmati panorama bawah laut seperti terumbu karang dan berinteraksi dengan ikan secara langsung.

Snorkeling (selam permukaan) atau selam dangkal (skin diving) adalah kegiatan berenang atau menyelam dengan mengenakan peralatan berupa masker selam dan snorkel. Selain itu, penyelam sering mengenakan alat bantu gerak berupa kaki katak (sirip selam) untuk menambah daya dorong pada kaki. Jadi, pada dasarnya snorkeling hanya dilakukan di permukaan saja. Karena menggunakan peralatan yang sangat standard, snorkeling hanya dapat dilakukan di siang hari karena sangat mengandalkan sinar matahari.

Pariwisata bahari dengan konsep ekowisata adalah Pantai Pemuteran yang berlokasi di Desa Pemuteran, Kecamatan Gerokgak Perpaduan ketenangan alam pantai serta keindahan alam bawah laut, menjadikannya sebagai kawasan ekowisata yang diminati oleh wisatawan mancanegara. Desa Pemuteran merupakan gambaran wisata bahari keindahan taman laut di Bali Barat. Pantai Pemuteran merupakan kawasan dengan konservasi laut terumbu karang artifisal "Biorock" dan diterapkan Yayasan Karang Lestari. Masyarakat Desa Pemuteran ikut bergerak aktif dalam mengelola pelestarian terumbu karang di laut Pemuteran. Wisata bahari Pemuteran atau sekitar 55 $\mathrm{km}$ arah barat kota Singaraja merupakan daerah wisata berupa gugusan perbukitan serta hamparan laut utara Bali sehingga membuat daerah ini indah, tenang, jauh dan dari keramaian. Hal yang menjadikan Desa Pemuteran memiliki ciri khas yaitu menyajikan pemandangan pura (candi) yang berada di bawah laut sehingga menjadikan tempat ini unik.

\subsection{Kendala}

Kendala dalam pengelolaan potensi sumberdaya pesisir di Desa Pemuteran yaitu Upaya dalam pengelolaan terumbu karang di Pemuteran membutuhkan kemauan, komitmen serta modal yang besar. Apalagi penggunaan teknologi biorock membutuhkan bantuan aliran listrik untuk menstimulus pertumbuhan karang. Ikan yang telah ditangkap para nelayan sebagian besar dijual ke luar daerah. Nelayan di Desa Pemuteran memerlukan sarana dan prasarana yang memadai melihat dari sulitnya pemasaran ikan dan belum ada fasilitas pelelangan ikan.

Pariwisata identik dengan keindahan dan Kebersihan, keindahan dan kebersihan mencerminkan budaya suatu bangsa. Namun Sepanjang pantai pemuteran masih ada sampah-sampah akibat hujan kiriman yang ada, hal inilah yang menjadikan 
kendala dalam perkembangan suatu pariwisata di Desa Pemuteran. Sampah masih menjadi permasalahan di Desa Pemuteran, belum adanya penanggulangan masalah kebersihan pantai secara umum, hanya pantai yang dikelola oleh instansi wisata yang terkelola dengan baik.

\subsection{Strategi Pengelolaan Sumberdaya Pesisir di Desa Pemuteran.}

Tabel 1.Analisis SWOT Pengelolaan Sumberdaya Pesisir

\begin{tabular}{|c|c|c|}
\hline Internal & $\begin{array}{l}\text { Opportunities (0) } \\
\text { Peluang } \\
-\quad \text { Permintaan ikan tinggi } \\
-\quad \text { Jumlah wisatawan meningkat } \\
-\quad \text { Permintaan garam tinggi }\end{array}$ & $\begin{array}{l}\text { Threatst (T) } \\
\text { Ancaman } \\
-\quad \text { Produksi ikan } \\
\quad \text { perusahaan } \\
\text { - } \quad \text { Pencemaran pantai } \\
\text { - } \quad \text { Pemasaran garam sulit }\end{array}$ \\
\hline $\begin{array}{l}\text { Strengths (S) } \\
\text { Kekuatan } \\
-\quad \text { Potensi ikan } \\
-\quad \text { Memiliki daya tarik } \\
\quad \text { wisata } \\
\text { - } \quad \text { Industri garam }\end{array}$ & $\begin{array}{l}\text { - Menambah tambak ikan dan } \\
\text { udang } \\
\text { - Pemetaan sebaran terumbu } \\
\text { karang (spot diving dan } \\
\text { snorkling) } \\
\text { - Menambah industri garam }\end{array}$ & 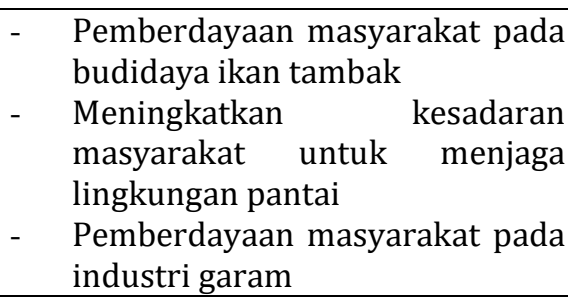 \\
\hline $\begin{array}{l}\text { Weaknesses (W) } \\
\text { Kelemahan } \\
\text { - } \quad \text { Tidak ada pasar ikan } \\
\text { - } \quad \text { Biaya pengelolaan } \\
\text { terumbu karang tinggi } \\
\text { - Usaha industri tidak } \\
\text { ada }\end{array}$ & $\begin{array}{ll}\text { - } & \text { Mendirikan TPI (Tempat } \\
\text { Pelelangan ikan) } \\
\text { - } & \text { Pemberdayaan masyarakat } \\
\text { terhadap industri kegiatan } \\
\text { untuk kebutuhan pariwisata } \\
\text { - } \begin{array}{l}\text { Membuat perjanjian } \\
\text { kerjasama dengan pihak } \\
\text { pelaku usaha wisata }\end{array}\end{array}$ & 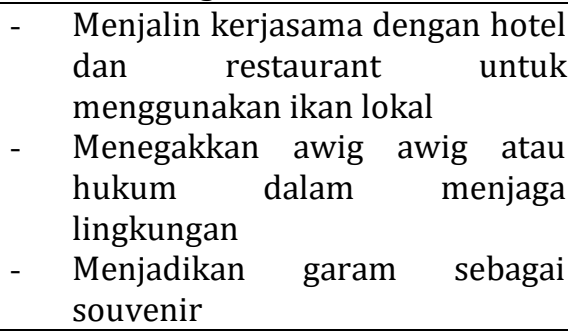 \\
\hline
\end{tabular}

\section{Simpulan dan Saran}

Desa Pemuteran memiliki berbagai potensi sumberdaya pesisir yang sudah dikembangkan yaitu sumberdaya hayati, sumberdaya non-hayati, sumberdaya buatan dan jasa-jasa lingkungan berupa wisata bahari seperti diving dan snorkling serta industri garam lokal dan budidaya ikan kerapu yang saat ini dalam proses pengembangan.Kendala dalam pengelolaan potensi sumberdaya pesisir di DesaPemuteran diantaranyaketerbatasan sarana pemasaran ikan dan pengolahan ikan,rendahnya kualitas sumber daya manusia dalam menjaga ekosistem terumbu karang, kurangnya partisipasi pemerintah terhadap penanggulangan kerusakanterhadap ekosistem pesisir pantai.Strategi pengelolaan sumberdaya pesisir di Desa Pemuteran dintaranya: a) sumberdaya ikan yakni pembudidayaan ikan, menambah produk oerikanan dalam daerah, menyediakan TPI, memberikan batasan masuknya produk perikanan dari luar daerah; b) pelestarian terumbu karang, penegakan hukum dan awig-awig beserta sanksinya, memberikan pelatihan terhadap masyarakat tentang pelestarian terumbu karang, meningkatkan kesadaran masyarakat 
tentang pentingnya menjaga sumberdaya terumbu karang; c) pariwisata dalam hal pelatihan pelayanan wisata, pemeliharaan lingkungan pantai agar tetap asri dan nyaman, menjaga potensi wisata dengan baik; d) kerajinan yakni memberikan modal kepada masyarakat dalam bidang usaha yang ditekuni di Desa Pemuteran, menjalin kerja sama dengan pelaku wisata baik swasta maupun pemerintah dalam meningkatkan produk kerajinan.

Hasil dari penelitian ini diharapkan nantinya masyarakat setempat terus menjaga dan meningkatkan partisipasinya dalam pengelolaan sumberdaya pesisir di Desa Pemuteran dan mampu memberikan inovasi baru guna mendukung pengembangan potensi sumberdaya pesisirBagi pemerintah diharapkan bergerak aktif dalam mempromosikan dan memberikan informasi langsung mengenai Desa Pemuteran sebagai desa wisata yang nantinya diperhitungkan di Bali serta memberikan pelatihan guna meningkatkan kualitas sumberdaya manusia dalam Pengelolaan Sumberdaya Pesisir Di Desa Pemuteran.Hasil dari penelitian ini diharapkan dapat dijadikan refrensi atau acuan bagi peneliti lain yang berminat melakukan penelitian sejenis, dapat digunakan sebagai pertimbangan atau perbandingan dengan memperhatikan kendalakendala yang dialami.

\section{Daftar Referensi}

As-Syakur, A. R., \& Wiyanto, D. B. (2016). Studi Kondisi Hidrologis Sebagai Lokasi Penempatan Terumbu Buatan di Perairan Tanjung Benoa Bali. Jurnal Kelautan, 9(1), 85-92.

Budiharsono, S. (2001). Teknik analisis pembangunan wilayah pesisir. Jakarta: Pradnya Paramita.

Dahuri, R. (1999). Pendayagunaan Sumberdaya Kelautan untuk Kesejahteraan Rakyat.

Khakhim, N., Soedharma, D., Mardiastuti, A., Siregar, V. P., \& Boer, M. (2008). Analisis Preferensi Visual Lanskap Pesisir Daerah Istimewa Yogyakarta Untuk Pengembangan Pariwisata Pesisr Menuju Pada Pengelolaan Wilayah Pesisir Berkelanjutan. Forum Geografi, 22(1), 44-59.

Sadono, E. D. (2017). Desentralisasi dan Pengelolaan Wilayah Pesisir di Indonesia Studi Pada Desa Kohod Kecamatan Pakuhaji Kabupaten Tangerang. Kawistara, 7(3), 275284.

Sudiartawan, I. K., Treman, I. W., \& Budiarta, I. G. (2017). Studi Pengelolaan Sumber Daya Pesisir di Desa Batununggul Kecamatan Nusa Penida. Jurnal Jurusan Pendidikan Geografi, 5(2).

Sutrisno, E. (2014). Implementasi Pengelolaan Sumber Daya Pesisir Secara Terpadu Untuk Kesejahteraan Nelayan. Jurnal Dinamika Hukum, 14(1), 1-12.

Uar, N. D., Murti, S. H., \& Hadisusanto, S. (2016). Kerusakan Lingkungan Akibat Aktivitas Manusia Pada Ekosistem Terumbu Karang. Majalah Geografi Indonesia, 30(1), 8895.

Waluyo, A. (2014). Permodelan Pengelolaan Wilayah Pesisir dan Pulau Pulau Kecil Secara Terpadu yang Berbasis Masyarakat (Studi Kasus Pulau Raas Kabupaten Sumenep Madura). Jurnal Kelautan, 7(2), 75-85.

Yudasmara, G. A. (2016). Pengelolaan Kawasan Pesisir Kabupaten Buleleng Melalui Pengembangan Mina Wisata Bahari. Jurnal Manusia Dan Lingkungan, 23(3), 381389. 